(c) Group of authors, 2021

UDC 616.24-002-053.3/.5

DOI - https://doi.org/10.14300/mnnc.2021.16032

ISSN - 2073-8137

\title{
PREDICTIVE ROLE OF BACTERICIDAL/PERMEABILITY-INCREASING PROTEIN AND C-REACTIVE PROTEIN IN A PERSONALIZED APPROACH TO THE TREATMENT OF CHILDREN WITH ACUTE PNEUMONIA
}

Golubeva M. V. ${ }^{1}$, Rakitina E. N. ${ }^{1}$, Minaev S. V. ${ }^{1}$, Kirgizov I. V. ${ }^{2}$, Obedin A. N. ${ }^{1}$, Akselrov M. A. ${ }^{3}$, Barova N. K. ${ }^{4}$, Bochnyuk E. A. ${ }^{5}$

1 Stavropol State Medical University, Russian Federation

2 Russian Medical Academy of Continuing Professional Education, Moscow,

Russian Federation

${ }^{3}$ Tyumen State Medical University, Russian Federation

${ }^{4}$ Kuban State Medical University, Krasnodar, Russian Federation

${ }^{5}$ City Clinical Consultative and Diagnostic Polyclinic, Stavropol, Russian Federation

\section{ПРОГНОСТИЧЕСКАЯ РОАЬ АНТИМИКРОБНОГО БЕАКА, ПОВЫШАЮЩЕГО ПРОНИЦАЕМОСТЬ КАЕТОК, И С-РЕАКТИВНОГО БЕАКА ПРИ ПЕРСОНААИЗИРОВАННОМ ПОАХОАЕ К АЕЧЕНИЮ АЕТЕЙ С ОСТРЫМИ ПНЕВМОНИЯМИ}

\author{
М. В. Голубева ${ }^{1}$, Е. Н. Ракитина ${ }^{1}$, С. В. Минаев ${ }^{1}$, И. В. Киргизов ${ }^{2}$, А. Н. Обеаин ${ }^{1}$, \\ М. А. Аксельров ${ }^{3}$, Н. К. Барова ${ }^{4}$, Е. А. Бочнюк ${ }^{5}$ \\ ${ }^{1}$ Ставропольский госуАарственный меАицинский университет, \\ Российская ФеАерация \\ 2 Российская меАицинская акаАемия непрерывного профессионального образования, \\ Москва, Российская ФеАерация \\ 3 Тюменский госуАарственный МеАицинский университет, Российская ФеАерация \\ ${ }^{4}$ Кубанский ГосУАарственный МеАицинский Университет, КрасноАар, \\ Российская ФеАерация \\ 5 ГороАская кАиническая консультативно-Аиагностическая поликАиника, \\ Ставрополь, Российская ФеАерация
}

Our prospective nonrandomized controlled study enrolled 165 children with acute pneumonia (AP) from 2 to 18 years of age, which included 51 (30.9 \%) children with ANP. There were 91 (55.2 \%) boys and 73 (44.8 \%) girls. Dynamic complex determination of BPI and CRP concentrations in blood serum from children with AP was a sensitive indicator to predict the development of complications and ANP. High levels of BPI and CRP in children with AP were prognostic signs for good outcomes of the disease. In the presence of an initially low BPI level $(<10 \mathrm{ng} / \mathrm{ml})$ and high CRP $(>100 \mathrm{mg} / \mathrm{L})$, disease progression was noted, which included the development of bronchopleural complications.

Keywords: acute pneumonia, $\mathrm{BPI}, \mathrm{CRP}$, necrotizing pneumonia, inflammation, children

В проспективное нерандомизированное контролируемое исследование были включены 165 детей от 2 до 18 лет с острой пневмонией, в том числе 51 (30,9\%) ребенок с острой гнойно-деструктивной пневмонией (ОГДП). Мальчиков было 91 (55,2 \%), девочек - 73 (44,8 \%). Динамическое комплексное определение концентрации антимикробного белка, повышающего проницаемость клеток (BPI), и СРБ в сыворотке крови у детей с острой пневмонией является чувствительным показателем в прогнозировании развития осложнений и ОГДП. Высокий уровень ВРІ и СРБ у детей с острой пневмонией является благоприятным прогностическим признаком в отношении исхода заболевания. При наличии исходно низкого уровня ВРІ (менее 10 нг/мл) и высокого уровня СРБ (более 100 мг/л) отмечается неблагоприятное течение заболевания, включая и развитие бронхоплевральных осложнений.

Ключевые слова: острая пневмония, антимикробный белок, повышающий проницаемость клеток, СРБ, ОГДП, воспаление, дети

For citation: Golubeva M. V., Rakitina E. N., Minaev S. V., Kirgizov I. V., Obedin A. N., Akselrov M. A., Barova N. K., Bochnyuk E. A. PREDICTIVE ROLE OF BACTERICIDAL/PERMEABILITY-INCREASING PROTEIN AND C-REACTIVE PROTEIN IN A PERSONALIZED APPROACH TO THE TREATMENT OF CHILDREN WITH ACUTE PNEUMONIA. Medical News of North Caucasus. 2021;16(2):144-148. DOI - https://doi.org/10.14300/mnnc.2021.16032 
Для цитирования: Голубева М. В., Ракитина Е. Н., Минаев С. В., Киргизов И. В., Обедин А. Н., Аксельров М. А., Барова Н. К., БОчНЮК Е. А. ПРОГНОСТИЧЕСКАЯ РОЛЬ АНТИМИКРОБНОГО БЕЛКА, ПОВЫШАЮЩЕГО ПРОНИЦАЕМОСТЬ КЛЕТОК, И С-РЕАКТИВНОГО БЕЛКА ПРИ ПЕРСОНАЛИЗИРОВАННОМ ПОДХОДЕ К ЛЕЧЕНИЮ ДЕТЕЙ С ОСТРЫМИ ПНЕВМОНИЯМИ. Медицинский вестник Северного Кавказа. 2021;16(2):144-148.

DOI - https://doi.org/10.14300/mnnc.2021.16032

AD - antibacterial drug

ANP - acute necrotizing pneumonia

AT - antibiotic therapy

BPI - bactericidal permeability-increasing protein

EBV - Epstein-Barr virus

\author{
ELISA - enzyme-linked immunosorbent assay \\ CMV - cytomegalovirus \\ CRP - C-reactive protein \\ PCR - polymerase chain reaction
}

$\mathbf{P}$ redicting the course of the inflammatory reaction and the development of complications in children with acute pneumonia (AP) has been difficult [1-5]. The result of the inflammatory process is associated with impaired permeability of cell membranes and subsequent translocation of microflora through the alveolar epithelium and basement membrane [6-9].

Interest in proteins of the acute phase of inflammation (e.g., CRP, serum amyloid $\mathrm{P}$, and mannose-binding lectins) remains invariably high. Studies of endogenous antimicrobial peptides are gaining increasing attention, particularly bactericidal/permeability-increasing protein (BPI) [10-12]. BPI is a neutrophilic derived protein and the prototype of the tubular lipid-binding protein family. A study has described the location and effectiveness of $\mathrm{BPI}$ in gram-negative and -positive bacteremia and sepsis [13]. Additionally, the serum BPI concentration increases not only during inflammatory diseases, but also during allergic reactions [14]. Because of the limited number of studies devoted to comprehensive assessment of BPI and CRP levels during the progression of AP and acute necrotizing pneumonia (ANP) in children, this research area is relevant and in demand.

This study aimed to comprehensively assess the effect of BPI and CRP levels on the development of AP in children.

Material and Methods. The prospective nonrandomized controlled study included 165 children aged 2-18 years with a respiratory tract infection accompanied by development of pneumonia, which included 51 (30.9\%) children with ANP. There were 91 boys (55.2\%) and 73 girls (44.8\%).

This study was carried out by following the requirements of biomedical ethics of the Geneva Convention on Human Rights (1997) and the Declaration of Helsinki of the World Medical Association (2000) and received permission from the local ethics committee, which included informed consent from parents and patients for inclusion in the study.

Analysis of children with AP revealed a predominance of patients of preschool age (3-6 years) [64 (38.8\%) children], which included 37 boys (22.4\%) and 27 girls $(16.9 \%)$. The distribution of patients by age and sex is shown in the Figure.

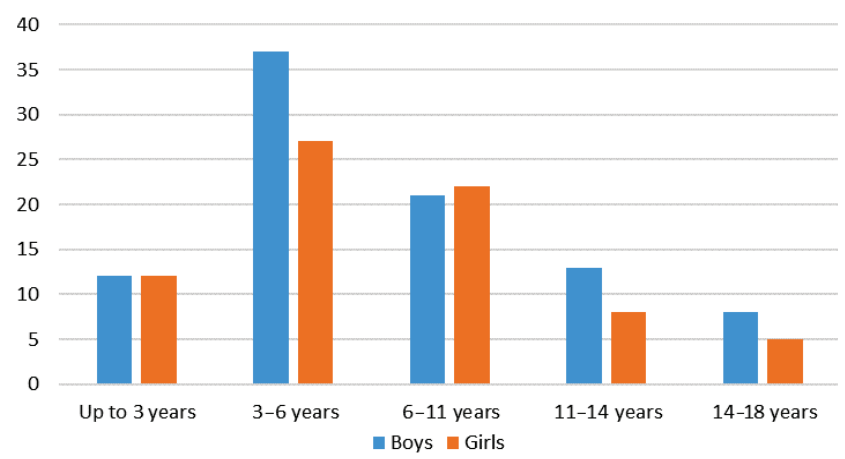

Fig. Distribution of patients with AP by age and sex
Patients with AP were admitted to hospital on average at $10.3 \pm 0.6$ days from the onset of disease. Early diagnosis and hospitalization at 3-7 days from the beginning of the disease had occurred for 58 (35.2\%) children. Additionally, admission to the hospital for more than half of the cases [107 (64.8\%)] was late (later than 8 days from the onset of the disease).

The criteria for inclusion of patients in the study were as follows. Age of patients: 2-18 years; X-ray-confirmed diagnosis of pneumonia; absence of severe concomitant pathology; absence of allergic reactions to administration of drugs; signing voluntary consent for participation in this study by patients and their parents.

Exclusion criteria for patients were as follows. Age of patients: under 2 or over 18 years; absence of a radiographically confirmed diagnosis of AP; previous hospitalization of the patient in a hospital that required the use of ABT within a period of up to 30 days; nosocomial pneumonia; concomitant somatic and infectious diseases; the use of glucocorticoids; refusal of patients and their parents to participate in this study.

Children were divided into three groups: group 1 included 82 (49.7\%) patients with AP; group 2 included $32(19.4 \%)$ children who had progression or lack of dynamics in the treatment of AP in the course of treatment; group 3 included 51 (30.9\%) patients with ANP. The control group consisted of 25 healthy children admitted to somatic and surgical departments for non-infectious diseases (e.g., inguinal hernia and intestinal colic).

Children underwent clinical and instrumental examinations that included laboratory techniques that followed generally accepted standards (e.g., general blood and urine analyses, biochemical blood tests, including total protein and its fractions, total bilirubin and fractions, transaminases, urea, and creatinine). Upon admission, all patients underwent microbiological analyses that included smear prints from the mucous membrane of the upper respiratory tract for microflora and sensitivity to $A B T$ as well as PCR testing for respiratory viruses. During the course of treatment, all children underwent an ELISA of blood plasma to detect chlamydia, toxoplasma, mycoplasma, EpsteinBarr virus, CMV, and herpes simplex virus types I and II.

Along with laboratory examinations, patients underwent ultrasound of the pleural cavity and pulmonary parenchyma and X-ray examination (plain radiography and CT).

Dynamic monitoring of CRP in children with AP was carried out at the bedside using a portable immunochromatographic express analyzer Easy-Reader (VedaLab, Alençon, France). In blood sera of children with AP, BPI was measured by an ELISA in an automatic analyzer using a standard set of reagents. For this analysis, we used reagents from BCM Diagnostics (Elston Way, Woodland, USA). Blood analyses for the levels of CRP and BPI in blood plasma from children were carried out upon admission and on the third and $14^{\text {th }}$ days after the patient was admitted to hospital.

Patients received complex etiotropic, pathogenetic, and symptomatic therapies for the underlying disease and concomitant pathology. 
Analysis of the differences among groups was carried out by variation statistics using Microsoft Excel 2010 (Microsoft Office, USA) and Statistica 10.0 (StatInc, USA). The normality of the distribution of variation series was checked using Kolmogorov and Shapiro-Vilks goodness-of-fit tests. Correlation analysis in accordance with Mann-Whitney was carried out by calculation of the U-empirical criterion and determination of the zone in which the results were located (significance, uncertainty, and insignificance).

Results and Discussion. All children with AP showed a significant increase in the concentration of antimicrobial proteins that increased the permeability of BPI cells compared with healthy children $(p<0.01)$ (Table 1). This unambiguously revealed a pronounced anti-inflammatory response in children with pneumonia.

The changes in the concentration of bactericidal protein BPI among patients showed that its baseline level had increased in all groups throughout the study, which reached a maximum by 14 days.

\section{BPI concentration $(M \pm m)$ in blood serum} of children in the study groups $(\mathrm{ng} / \mathrm{ml})$

\begin{tabular}{|c|c|c|c|c|}
\hline $\begin{array}{l}\text { Research } \\
\text { timing }\end{array}$ & $\begin{array}{l}\text { Compa- } \\
\text { rison } \\
\text { group } \\
n=25\end{array}$ & $\underset{n=82}{\text { Group }} 1$ & $\underset{n=32}{\text { Group }} 2$ & $\underset{n=51}{\text { Group }} 3$ \\
\hline $\begin{array}{l}\text { Upon } \\
\text { hospital } \\
\text { admission }\end{array}$ & \multirow{3}{*}{$2.2 \pm 0.5$} & $15.8 \pm 3.1$ & $17.3 \pm 2.2$ & $9.5 \pm 1.8 * *$ \\
\hline $\begin{array}{l}\text { On the third } \\
\text { day of inpa- } \\
\text { tient treat- } \\
\text { ment }\end{array}$ & & $21.7 \pm 2.5$ & $17.9 \pm 2.6$ & $16.2 \pm 3.3$ \\
\hline $\begin{array}{l}\text { On day } 14 \\
\text { of inpatient } \\
\text { treatment }\end{array}$ & & $24.4 \pm 3.6$ & $23.1 \pm 2.8$ & $33.6 \pm 4.5^{\#}$ \\
\hline
\end{tabular}

${ }^{* *}$ - in comparison, groups 2 and $3-p<0.01$.

\# - within the group in comparison upon admission and on day $14-p<0.01$.

Moreover, each group had its own level of increase in the studied parameters. Therefore, group $1 \mathrm{had}$ a progressive increase in the BPI concentration from admission to the period of convalescence $(15.8 \pm 3.1$ and $24.4 \pm 3.6 \mathrm{ng} /$ $\mathrm{ml}$, respectively). In group 2, there was a feature associated with «stagnation" of the BPI level at $17.9 \pm 2.6 \mathrm{ng} / \mathrm{ml}$ in comparison with its increase in group $1(21.7 \pm 2.5 \mathrm{ng} / \mathrm{ml})$. This indicated the need to revise the treatment program, which included correction of ABT. The correction led to a good treatment result and equalization of the BPI concentration during the recovery period in both groups.

In group 3 children with ANP, the concentration of $\mathrm{BPI}$ was much lower than in children with $\mathrm{AP}$, which was $9.5 \pm 1.8 \mathrm{ng} / \mathrm{ml}$. Against the background of adequately conducted treatment, a significant increase to $33.6 \pm 4.5 \mathrm{ng} / \mathrm{ml}$ was noted by the $14^{\text {th }}$ day $(p<0.05)$.

The serum level of CRP in children was significantly decreased from admission to 14 days of hospitalization $(p<0.01)$ and was significantly high in all children at the time of hospitalization in comparison with healthy respondents $(p<0.01)$ (Table 2$)$. The dynamics of CRP demonstrated the adequacy of the therapeutic measures in patients with pneumonia.

Similar to the changes associated with BPI, the individual characteristics of the change in concentration were recorded for each group. In groups 1 and 2, there was a progressive decrease in the level of CRP in blood plasma from admission to the period of recovery $(98.7 \pm 15.1$ and $2.2 \pm 0.6 \mathrm{mg} / \mathrm{L} ; 112.4 \pm 27.9$ and $2.9 \pm 0.4 \mathrm{mg} / \mathrm{L}$, respectively). In group 2, there was a higher CRP level than in group 1. A high baseline BOP rate required closer attention from the attending physician. The changes in the CRP level among patients with ANP showed the highest rates among all participants upon admission to the hospital (136.5 $\pm 8.7 \mathrm{mg} / \mathrm{L})$.

Serum CRP level $(M \pm m)$ in children

Table 2 in the study groups $(\mathrm{mg} / \mathrm{L})$

\begin{tabular}{|c|c|c|c|c|}
\hline $\begin{array}{l}\text { Research } \\
\text { timing }\end{array}$ & $\begin{array}{l}\text { Com- } \\
\text { parison } \\
\text { group } \\
\mathrm{n}=25\end{array}$ & $\begin{array}{c}\text { Group } \\
n=82\end{array}$ & $\underset{n=32}{\operatorname{Group}} 2$ & $\underset{n=51}{\text { Group }} 3$ \\
\hline $\begin{array}{l}\text { Upon hos- } \\
\text { pital admis- } \\
\text { sion }\end{array}$ & \multirow{3}{*}{$2.1 \pm 0.3$} & $98.7 \pm 15.1$ & $112.4 \pm 27.9$ & $136.5 \pm 18.7$ \\
\hline $\begin{array}{l}\text { On the third } \\
\text { day of inpa- } \\
\text { tient treat- } \\
\text { ment }\end{array}$ & & $44.1 \pm 5.9$ & $56.4 \pm 7.5$ & $70.6 \pm 9.3^{8}$ \\
\hline $\begin{array}{l}\text { On day } 14 \\
\text { of inpatient } \\
\text { treatment }\end{array}$ & & $2.2 \pm 0.6^{\#}$ & $2.9 \pm 0.4^{\#}$ & $4.9 \pm 1.2^{\#, ~ \& ~}$ \\
\hline
\end{tabular}

$\&$ - in comparison, groups 1 and $3-p<0.05$.

\# - within the group in comparison upon admission and on day $14-p<0.01$.

On the basis of the results of dynamic determination of $\mathrm{BPI}$ and CRP concentrations, we analyzed the dynamics and trends of their changes, which allowed us to not only to predict the development of a complicated course of AP in children, but also correct the treatment.

With a complicated course of AP in children and initially high serum concentrations of BPI and CRP in patients from the onset of illness, by the third day of inpatient treatment, stagnation of the BPI concentration was noted. However, a decrease in CRP was observed, but it did not reach the range of values of the uncomplicated course of AP. This combination of serum BPI and CRP suggested a change in the treatment approach, which included correction of the antibiotic therapy. Modification of the treatment program provided a favorably high concentration of BPI with a low serum CRP level by the $14^{\text {th }}$ day.

Endogenous antimicrobial peptides and proteins are essential components of the innate immune system that protects against various bacteria, fungi, and viruses [15]. $\mathrm{BPI}$ is abundant in primary azurophilic granules and is associated with the airway epithelial cell surface $[16,17]$. During $\mathrm{AP}, \mathrm{BPI}$ is central to antimicrobial protection. During phagocytic uptake of bacteria by neutrophфils, primary granules rapidly degranulate in the phagosome, which leads to direct destruction of pathogens by very high local concentrations of BPI and other antimicrobial peptides [18].

In children with early clinical manifestations of sepsis, the BPI level increases significantly and is comparable to that in adults with bacteremia or pneumonia. In this regard, it is very promising to determine $\mathrm{BPI}$ in plasma as a marker of systemic inflammation and bacterial infection. Additionally, BPI is an endogenous inhibitor of angiogenesis by inducing apoptosis of vascular endothelial cells $[19,20]$.

$\mathrm{BPI}$ is a marker for various diseases. Autoantibodies against BPI are a serological marker of inflammatory diseases such as cystic fibrosis of the pancreas, vasculitis, and primary sclerosing cholangitis. BPI concentrations in plasma and synovial fluid of patients with rheumatoid arthritis correlate with disease activity [21-23].

Determination of only BPI in AP does not always lead to a positive and unambiguous interpretation of the study result. Thus, the authors did not detect an increase in anti-BPI IgA in saliva. However, the mucous surface is where bacteria with neutrophils are present, which accumulate 
during the infectious process $[24,25]$. However, saliva may have an unusual BPI concentration [21].

Our study found that a comprehensive dynamic survey of the concentrations of BPI and CRP in blood sera of children with AP is a sensitive indicator to predict the development of complications and ANP.

Conclusions. A high BPI level with an accompanying high serum CRP level in children with a respiratory tract infection upon admission to a hospital is a favorable prognostic sign for the outcome of the disease. An initially low BPI level in blood serum $(<10 \mathrm{ng} / \mathrm{ml})$ in children with a high level of CRP (>100 mg/L) is a marker of an unfavorable course of the disease and the development of pulmonary-pleural complications. Determination of the dynamics of BPI and CRP concentrations in children with AP may serve as an early predictor for changes in treatment tactics.

Information on the sources of financing

The study was carried out within the framework of the academic project «Development of research in the field of clinical medicine» of the Stavropol State Medical University Development Program.

Disclosures: The authors declare no conflict of interest.

Acknowledgment. We thank Mitchell Arico from Edanz (https://www.edanz.com/ac) for editing a draft of this manuscript.

\section{References}

1. Tarakanov V. A., Barova N. K., Shumlivaya T. P., Goloseev K. F., Kiselev A. N. Modern technology in the diagnosis and treatment of acute bacterial necrotizing pneumonia in children. Russian Journal of Pediatric Surgery, Anesthesia and Intensive Care. 2015;5(1):50-56.

2. Barycheva L. Yu., Golubeva M. V., Kuzmina E. S., Rakitina E. N. Congenital infections and congenital malformation in children. Medical News of North Caucasus. 2019;14(3):5 08-512. https://doi.org/10.14300/mnnc.2019.14125

3. Minaev S. V., Filipeva N. V., Leskin V. V., Shchetinin E. V., Golubeva M. V. [et al.] Microbiological spectrum of pyoinflammatory diseases causative agents in children at a multi-speciality hospital. Medical News of North Caucasus. 2018;13(1):112-114.

https://doi.org/10.14300/mnnc.2018.13032

4. Tong S. Y. C., Davis J. S., Eichenberger E., Holland T. L., Fowler V. G. Staphylococcus aureus infections: epidemiology, pathophysiology, clinical manifestations, and management. Clin. Microbiol. Rev. 2015;28(3):603-66. https://doi/org/10.1128/CMR.00134-14

5. Benedictis F. M., Kerem E., Chang A. B., Colin A. A., Zar H. J. [et al.] Complicated pneumonia in children. Lancet. 2020;396(10253):786-798.

https://doi/org/10.1016/S0140-6736(20)31550-6

6. Vecherkin V. A., Toma D. A., Ptitsyn V. A., Koryashkin P. V. Destructive pneumonias in children. Russian Journal of Pediatric Surgery, Anesthesia and Intensive Care. 2019:9(3):108-115.

https://doi.org/10.30946/2219-4061-2019-9-3-108-115

7. Gross I., Gordon O., Cohen-Cymberknoh M., Reiter J., Tsabari R. [et al.] Giant lung cysts following necrotizing pneumonia: resolution with conservative treatment. Pediatr Pulmonol. 2019;54(6):901-906 https://doi/org/10.1002/ppul.24321

8. Tsai Y. F., Ku Y. H. Necrotizing pneumonia: a rare complication of pneumonia requiring special consideration. Curr. Opin. Pulm. Med. 2012;18(3):246-252.

https://doi.org/10.1097/MCP.0b013e3283521022

9. Troeger C., Blacker B., Khalil I. A., Rao P. C., Cao J. [et al.] Estimates of the global, regional, and national morbidity, mortality, and aetiologies of lower respiratory infections in 195 countries, 1990-2016: a systematic analysis for the Global Burden of Disease Study 2016. The Lancet Infectious Diseases. 2018;18(11):1191-1210. https://doi.org/10.1016/S1473-3099(18)30310-4

10. Margaroli C., Garratt L. W., Horati H., Dittrich A. S., Rosenow T. [et al.] Elastase Exocytosis by Airway Neutrophils Is Associated with Early Lung Damage in Children with Cystic Fibrosis. Am. J. Respir. Crit. Care Med. 2019;199(7):873881. https://doi.org/10.1164/rccm.201803-04420C

11. Liu M., Li H., Xue C. X., Gu L., Qu J. X. [et al.] Differences in inflammatory marker patterns for adult community-acquired pneumonia patients induced by different pathogens. Clin. Respir. J. 2018;12(3):974-985. https://doi.org/10.1111/crj.12614

12. Jauneikaite E., Tocheva A. S., Jefferies J. M. Current methods for capsular typing of Streptococcus pneumoniae. J. Microbiol. Methods. 2015;113:41-49. https://doi.org/10.1016/j.mimet.2015.03.006

13. Iwuji K., Larumbe-Zabala E., Bijlani S., Nugent K., Kanu A. [et al.] Prevalence of Bactericidal/Permeability-Increasing Protein Autoantibodies in Cystic Fibrosis Patients: Systematic Review and Meta-Analysis. Pediatr. Allergy. Immunol. Pulmonol. 2019;32(2):45-51.

https://doi.org/10.1089/ped.2018.0970
14. McQuillan K., Gargoum F., Murphy M. P., McElvaney O. J., McElvaney N. G. [et al.] Targeting IgG Autoantibodies for Improved Cytotoxicity of Bactericidal. Permeability Increasing Protein in Cystic Fibrosis. Front Pharmacol. 2020;11:1098. https://doi.org/10.3389/fphar.2020.01098

15. Janec K. J., Yuan H., Norton J. E., Kelner R. H., Hirt C. K [et al.] rBPI21 (Opebacan) promotes rapid trilineage hematopoietic recovery in a murine model of high-dose total body irradiation. Am. J. Hematol. 2018;93:1002-1013. https://doi.org/10.1002/ajh.25136

16. Saxena S., Atchison C., Cecil E., Sharland M., Koshy E., Bottle A. Additive impact of pneumococcal conjugate vaccines on pneumonia and empyema hospital admissions in England. J. Infect. 2015;71:428-436. https://doi.org/10.1016/j.jinf.2015.06.011

17. Madhi F., Levy C., Morin L., Minodier P., Dubos F. [et al.] Pneumonia Study Group, Béchet S, Varon E., Cohen R. GPIP (Pediatric Infectious Disease Group). Change in Bacterial Causes of Community-Acquired Parapneumonic Effusion and Pleural Empyema in Children 6 Years After 13-Valent Pneumococcal Conjugate Vaccine Implementation. J. Pediatric Infect. Dis. Soc. 2019;8(5):474-477. https://doi.org/10.1093/jpids/piy103

18. Pinkenburg O., Meyer T., Bannert N., Norley S., Bolte K. [et al.] The Human Antimicrobial Protein Bactericidal/Permeability-Increasing Protein (BPI) Inhibits the Infectivity of Influenza A Virus. PLoS One. 2016;11(6):e0156929. https://doi.org/10.1371/journal.pone.0156929

19. Liu S, Huang $Z$. Deng $X$, Zou X. Li H. [et al.] Identification of key candidate biomarkers for severe influenza infection by integrated bioinformatical analysis and initial clinical validation. J. Cell. Mol. Med. 2021;25(3):1725-1738. https://doi.org/10.1111/jcmm.16275

20. Liu J., Zhao $\mathrm{F}$. Lu J., Xu H., Liu $\mathrm{H}$. [et al.] High Mycoplasma pneumoniae loads and persistent long-term Mycoplasma pneumoniae DNA in lower airway associated with severity of pediatric Mycoplasma pneumoniae pneumonia. BMC Infect. Dis. 2019;19(1):1045.

https://doi.org/10.1186/s12879-019-4667-y

21. Steiner P., Otth M., Casaulta C., Aebi C. Autoantibodies against bactericidal/permeability-increasing protein (BPI) in children with acute pneumonia. FEMS Immunol. Med. Microbiol. 2009:57(2):125-128.

https://doi.org/10.1111/j.1574-695X.2009.00593.x

22. de Benedictis F. M., Carloni I. Management of necrotizing pneumonia in children: Time for a patient-oriented approach. Pediatr. Pulmonol. 2019;54(9):1351-1353. https://doi.org/10.1002/ppul.24412

23. Hoppe P. A., Holzhauer S., Lala B., Bührer C., Gratopp A [et al.] Severe infections of Panton-Valentine leukocidin positive Staphylococcus aureus in children. Medicine (Baltimore). 2019;98(38):e17185. https://doi.org/10.1097/MD.0000000000017185

24. Bülow S., Zeller L., Werner M., Toelge M., Holzinger J. [et al.] Bactericidal/Permeability-Increasing Protein Is an Enhancer of Bacterial Lipoprotein Recognition. Front Immunol. 2018;9:2768

https://doi.org/10.3389/fimmu.2018.02768

25. Frybova B., Koucky V., Pohunek P., Cejnarova K., Coufal S. Lung Resection in Children with Necrotizing Pneumonia: Outcome and Follow-up. Eur. J. Pediatr. Surg. 2021;31:129-134. https://doi.org/10.1055/s-0041-1725188 


\title{
About authors:
}

Golubeva Marina Viktorovna, MD, PhD, Professor, Head of the Department of children's infectious diseases; tel.: (8652)264312; e-mail: mmvg@rambler.ru; https://orcid.org/0000-0002-0225-3672

Rakitina Elena Nikolaevna, postgraduate student;

tel.: +79187618224; e-mail: rakitina_1989@bk.ru; https://orcid.org/0000-0003-0150-2662

Minaev Sergey Viktorovich, MD, PhD, Professor, Head of the Department of pediatric surgery; tel.: +79624507653; e-mail: sminaev@yandex.ru; https://orcid.org/0000-0002-8405-6022

Kirgizov Igor Vitalevich, MD, PhD, Professor, Professor of the Department of pediatric surgery; tel.: +79057720953; e-mail: drkirgizov@yandex.ru; https://orcid.org/0000-0001-5796-5266

Obedin Alexander Nikolaevich, MD, PhD, Associate Professor, Head of the Department of anesthesiology, reanimatology and emergency medical care; tel.: +79034169771; e-mail: volander@mail.ru; https://orcid.org/0000-0002-9990-7272

Axelrov Mikhail Alexandrovich, MD, PhD, Professor, Head of the Department of pediatric surgery;

tel.: +79292694933; e-mail: akselerov@mail.ru; https://orcid.org/0000-0001-6814-8894

Barova Natusya Kaplanovna, MD, CMSc, Associate Professor of the Department of pediatric surgery; tel.: 89882420449; e-mail: nbarova@yandex.ru: https://orcid.org/0000-0001-5857-2296

Bochnyuk Elena Aleksandrovna, MD, CMSc, Head of the clinical diagnostic laboratory; tel.: +79624464533; e-mail: kdplab@mail.ru; https://orcid.org/0000-0002-6014-0801

\section{IMMUNOGENETIC FEATURES OF DIFFERENT FORMS OF SECONDARY PYELONEPHRITIS IN CHILDREN}

\author{
Kulygina E. S. ${ }^{1}$, Razin M. P. ${ }^{1}$, Minaev S. V. ${ }^{2}$, Ignatiev S. V. ${ }^{3}$, \\ Akselrov M. A. ${ }^{4}$, Agalakova T. B. ${ }^{4}$ \\ ${ }^{1}$ Kirov State Medical University, Russian Federation \\ 2 Stavropol State Medical University, Russian Federation \\ 3 Kirov Research Institute of Hematology and Blood Transfusion, Russian Federation \\ ${ }^{4}$ Tyumen State Medical University, Russian Federation
}

\section{ИММУНОГЕНЕТИЧЕСКИЕ ОСОБЕННОСТИ РАЗАИЧНЫХ ФОРМ ВТОРИЧНОГО ПИЕАОНЕФРИТА У АЕТЕЙ}

\author{
Е. С. Кулыгина ', М. П. Разин ${ }^{1}$, С. В. Минаев ${ }^{2}$, С. В. Игнатьев ${ }^{3}$, \\ М. А. Аксельров ${ }^{4}$, Т. Б. Агалакова ${ }^{1}$
}

\footnotetext{
${ }^{1}$ Кировский госуАарственный МеАицинский университет, Российская ФеАерация

${ }^{2}$ Ставропольский госУАарственный МеАицинский Университет, Российская ФеАерация

${ }^{3}$ Кировский научно-исслеАовательский институт гематологии и переливания крови фелерального меАико-биологического агентства, Российская ФеАерация

4 Тюменский госуАарственный меАицинский университет, Российская ФеАерация
}

In recent years, many studies have documented an increased incidence of urinary system pathology in children, especially congenital anomalies of the urinary system with secondary pyelonephritis (SP). We carried out immunogenetic typing in 200 children aged 5-15 years with SP (100 children with latent SP and 100 children with recurrent SP). The distribution of human leukocyte antigen (HLA) alleles at the A, B, C, DR, DQ loci, as well as their phenotypic and haplotype combinations, was determined. We found that the latent course of SP in children was associated with interlocus combinations of the class 1 antigens HLA-A2/B17 and HLA-A3/B13. Resistance to latent SP was associated with the alleles HLA-DRB1*07, HLA-DRB1*15 (2), and HLA-DQB1 ${ }^{\star} 0302$, the phenotypic combinations of antigens HLA-A1/A9 and HLA-A9/A11, and the haplotype combinations HLA-A3/B7, HLA-A11/B35, and HLA-A19/B27. The recurrent course of SP in children was associated with the haplotype combination HLA-A11/B27. Resistance to recurrent SP was associated with the alleles HLA-DRB1*07, HLA-DRB1*09, and HLA-DRB1*15 (2), the intralocus antigenic combination HLA-A9/A11, and the interlocus combinations HLA-A2/B12, HLA-A3/ $B 7$, and HLA-A11/B35. In conclusions, HLA typing in children with various forms of SP enables the identification of factors predisposing to the development of this disease. These data may help clinicians understand the prognosis and disease course of various forms of SP. 